\title{
Ibsenov pharmakon: Sokrat i Stockmann
}

Abstract: Tomljenović Ana, Ibsenov pharmakon: Sokrat i Stockmann (Ibsen's Pharmakon: Socrates and Stockmann). "Poznańskie Studia Slawistyczne" 17. Poznań 2019. Publishing House of the Poznań Society for the Advancement of the Arts and Sciences, Adam Mickiewicz University, pp. 269-283. ISSN 2084-3011.

Although An Enemy of the People has always been one of Ibsen's most popular plays, ibsenology often dismisses it as a revolutionary pamphlet and the critique of the tyranny of the compact majority and the mediocrity of parliamentary democracy. Instead of focusing on the conflict that arises between the Conservatives and the Liberals, minority and majority, I want to draw attention to Ibsen's poetic revolt. Building on Derrida's study of the pharmakon in the Phaedrus, I argue that Ibsen continues to investigate the conflict between the speaker and the listener, between the actor and the audience, between speech and writing.

KEYwORDs: Ibsen; Plato; pharmakon; democracy

Unatoč tome što je Neprijatelj naroda (1882) oduvijek figurirao kao „jedan od Ibsenovih najpopularnijih komada“ (Van Laan, 1986, 95), ibsenologija nikada nije u tom pogledu potvrdila mišljenje publike. Stoga se i manjak kritičkog interesa za navedeni komad dade objasniti olako ponavljanom prosudbom kako je riječ o začuđujuće jednostavnom Ibsenovom djelu - dramskom tekstu u kojem se odveć izravno iznosi društveni komentar te zagovara jedna politička misao. S obzirom na to da komad nastaje neposredno nakon rasprave koja je buknula povodom praizvedbe Sablasti (1881), kritičari su požurili zaključiti kako je Ibsen napisao dramu ne bi li izvrgao ruglu „samozadovoljn[u], liberaln[u] većin[u]“ (Williams, 1979, 63) koja se zgražala nad njegovom tročinskom obiteljskom tragedijom. Slijedom navedenih interpretacijskih protokola koji nužno predmnijevaju izjednačenje neshvaćenog protagonista i ogorčenog dramatičara, Neprijatelj naroda počesto se svodio na polemički obračun ili „revolucionarni pamflet“ uperen protiv „tiranije čvrste većine“, odnosno 
„mediokriteta parlamentarne demokracije“ (Brustein, 1991, 71). U prilog toj tezi u kritičkoj se literaturi redovito spominje Ibsenova navodna identifikacija s vlastitim fikcionalnim likom, liječnikom Stockmannom, koja dodatno podržava sliku Ibsena, ne kao jednog od velikih dramskih pjesnika europske književnosti, nego kao učitelja, pedagoga, zdravstvenog djelatnika, društvenog kritičara ili reformatora.

Namjesto da raspravu zadržimo isključivo u ideološkim okvirima te Neprijatelja naroda proglasimo, kao što Robert Brustein predlaže, „dramom ideja“" (cf. Brustein, 1991, 72), u interpretaciji ćemo se usredotočiti na metakomunikacijsku dimenziju Ibsenova teksta, koja nam otkriva da je riječ o komadu u kojem se ideje zapravo ne uspijevaju ni priopćiti: slova se ne dadu otisnuti, a govor ne može izložiti. Suprotstavljajući se dakle čitanjima u kojima se tvrdi da je Ibsenov Neprijatelj naroda komad upravljen protiv demokracije kao političke ideje i društvenog poretka, u radu ćemo pokušati dokazati da je upravo demokracija tema koja Ibsenu omogućuje da metadramski raščini fantazam društvenog sklada i sloge, razumijevanja i priopćivosti, ili Derridinim riječima, fantazam „djevičanske čistoće i neprobijene unutrašnjosti““ (Derrida, 1981, 70). Ibsenov čuvar komunalne higijene i ljubitelj rasnih pasa, liječnik Stockmann, kreće naime u komično-herojsku borbu protiv nečistog identiteta: protiv antagonizma koji zatječe u središtu sociopolitičkog poretka. Budući da se Stockmannov protudemokratski diskurs ogleda prije svega u njegovu zagovoru čistih oblika - poziciji koja se u drami prispodobljuje metaforama iz životinjskog carstva, razlici između „obične kokoši“ i ,otmjenog fazana“ odnosno između ,čistokrvnih pudlica“ $\mathrm{i}$ „mješanaca“ se u tekstu razobličuje uzaludnost njegovih nastojanja da, kao doktor i kao pisac, otkloni nečistoću, drugost, razliku. Sagledamo li Ibsenovu dramu u intertekstnom okruženju Platonova dijaloga Fedar, u središtu kojeg se nalazi pojam pharmakon, u Ibsenovoj drami, umjesto čistoće ideje, raspoznat ćemo njezinu neuhvatljivost: neprekidno miješanje korisnosti i štetnosti demokracije, njezinih ljekovitih i pogubnih svojstava.

${ }^{1}$ Budući da prijevod Selimira Perišića izostavlja navesti spomenute metafore, ovdje upućujem na engleski prijevod (cf. Ibsen, 1978, 359). 
Ponavljajući početak Platonova dijaloga u kojem se Fedar otputio u šetnju prirodom slijedeći preporuke liječnika Akumena (cf. Platon, 1997, 3), u prvom prizoru Neprijatelja naroda saznajemo kako je Stockmann napustio gozbu zbog obvezatne šetnje koju prakticira ,iz zdravstvenih razloga“ (Ibsen, 1968, 8). Smjestivši radnju na ljetnu pozornicu izvan Atene, Platon u Fedru nije samo posebnu pozornost posvetio prirodnom okruženju unutar kojega se dijalog odvija, nego je sam ambijent pretvorio u predmet razgovora Sokrata i Fedra. S obzirom na to da je riječ o jedinom Platonovu dijalogu koji se odvija na otvorenom prostoru, zanimljivo je istaknuti da Platon odabire odvesti Sokrata i Fedra upravo do izvora čiste vode, vrela koje je, kao što ćemo vidjeti u nastavku, središnji topos Ibsenova Neprijatelja naroda. Nastojeći naime pronaći mirni kutak u kojem bi pročitali Lisijin govor, čiji primjerak Fedar drži u posjedu, Sokrat predlaže da krenu šetati uz obalu rijeke Ilis. Ugledavši najvišu platanu koja je pružala ugodan hlad, suputnici zastaju da se odmore na mjestu gdje „vrutak opet preliep teče [...] studene vode, kako se nogom osjetiti može“ (Platon, 1997, 7). Budući da su se zatekli na prostoru rijetke ljepote, gdje je „liepa i bistra i kao staklo vodica i prikladna djevojkama, da se kod nje igraju“ (Platon, 1997, 6), Fedar pomišlja da se nalaze upravo na onom mjestu odakle je Borej nasilno odveo Oritiju dok se igrala s Farmakijom. Iako Sokrat kazuje da mjesto radnje mitološke priče i njihova trenutna položaja nije isto - štoviše, vrlo precizno naznačuje lokaciju Borejine otmice - ovdje ne možemo propustiti naznačiti da se mjesto radnje Platonova dijaloga zrcali u Ibsenovoj drami. Budući da Sokrat i Fedar odabiru počinuti na mjestu koje nalikuje Farmakijinu izvoru, dakle vrelu iz kojeg se smatralo da izbija otrovna voda, i sami smo ponukani spekulirati poput Fedra te se zapitati: nalikuje li to mjesto na mjesto radnje Neprijatelja naroda, nije li se otrovna voda iz Platonova dijaloga prelila u Ibsenov komad i natopila fikcijske banje na jugu Norveške²?

$$
*
$$

${ }^{2}$ Iako su ibsenolozi nagađali o mogućem platonističkom izvorištu Neprijatelja naro$d a$, svoja su razmatranja uglavnom ograničili na dijaloge Republika i Obrana Sokratova, istaknuvši pri tome dvojništvo Stockmanna i Sokrata koje proizlazi iz, tvrdi Brian Johnson, upadljivih podudarnosti dramskog lika i povijesne ličnosti. Kako autor navodi u svojem radu, i Stockmann i Sokrat priželjkivali su društvo mladih ljudi, obojica su uživali u gozbama i pijankama, obojica su imali supruge koje se nisu u potpunosti slagale s njihovim odlukama te 
Liječnik Thomas Stockmann, protagonist Ibsenove drame, predstavlja se upravo kao slobodan mislilac i čovjek od pera: u prvome činu upoznajemo ga kao plodnog autora koji svoje radove objavljuje u liberalnom lokalnom časopisu Narodni glasnik. Osim što redovito piše obraćajući se pritom užem krugu publike ,kod koje[] se nada da će naći najviše odaziva“ (Ibsen, 1968, 9), Stockmann obavlja funkciju liječnika javnog kupališta. Prije no što se vratio živjeti u rodni grad, u primorsko mjestašce na jugu Norveške, Thomas je dugi niz godina proveo na dalekom Sjeveru, u podneblju u kojem vlada tišina, osama i oskudica. Opisujući kako je bilo živjeti „u svom usamljenom kutu“, Thomas najprije kazuje kako ondje nije imao sugovornike, tamo ,gotovo nikad ni[je] video čoveka s kojim bi[] mogao progovoriti pametnu reč“ (Ibsen, 1968, 12-13), a tek potom priznaje kako su on i njegova obitelj na drugom kraju zemlje patili od gladi i neimaštine. Budući da je poduže razdoblje proveo u socijalnoj izolaciji na drugom kraju zemlje, kritičari su u liku Thomasa Stockmanna prepoznali figuru stranca ${ }^{3}$, figuru koju ujedno rabi i Fedar ne bi li opisao Sokrata. Kao što Sokrat tvrdi da ga stabla neće ničemu naučiti, nego ljudi u gradu (cf. Platon, 1997, 7), tako je i Stockmann jedva dočekao povratak među ljude, odmah je u svojem domu započeo okupljati publiku, primati goste i organizirati gozbe i pijanke: „Ja koji sam tako dugo bio isključen iz svakoga društva moram oko sebe da vidim mlade, vesele ljude, ljude željne rada - a takvi ljudi su svi oni što tamo onako svojski jedu“ (Ibsen, 1968, 14). Dok je nekoć bez sugovornika skapavao na sjeveru, sada se neumjereno gosti riječima i časti tiradama u više sljedova. Pa ipak, unatoč tome što razgovor smatra duševnom hranom, Stokmann svoje subesjednike tretira upravo kao stabla koja Sokrat spominje, kao biljke od kojih nema što čuti.

Iskazujući pohvalu okruženju u kojem su se zatekli - hladu platane, mirisu njezina cvijeta, izvoru vode i vjetriću, travi i zboru cvrčaka - Sokrat kazuje „,[t]ako si baš liepo vodio stranca, o Phaidre“ (Platon, 1997, 7).

jednak broj djece, obojica su prognani iz zajednice dobrobiti kojoj su bili posvećeni te su obojica odbili otići u egzil (cf. Johnston, 2006, 136).

${ }^{3}$ Poput Stockmanna, koji utjelovljuje strano kao sjeverno tijelo u društvenom organizmu mjestašca na jugu Norveške, šačica njegovih istomišljenika dijeli sklonost tuđini: prva je njegova kći Petra, koja prevodi sa stranih jezika, a drugi je kapetan Horster, koji plovi dalekim morima. 
Fedrov zaključak ${ }^{4}$ ne potvrđuje samo Sokratov položaj stranca kao čudaka, čovjeka neobičnih značajki i iznimnog pojedinca, nego upućuje da se njegovo osobenjaštvo prije svega tiče funkcije koju u zajednici zauzima, položaja koji daje naslutiti njegovu unutrašnju izmještenost, položaja onoga tko je ,istodobno izvan i unutar zajednice“ (Miller, 2007, 132). Kako sugerira u svojoj analizi Giovanni R. F. Ferrari, upućujući na etimologiju riječi atopōtatos tis: Sokrat se „ponaša kao stranac iako je rođeni Atenjanin“ (Ferrari, 1987, 13-14). Budući da obojicu upoznajemo kao neudomaćene ili neprilagođene pojedince, a opet kao pojedince koji djeluju isključivo za dobrobit zajednice te velike rodoljube ${ }^{5}$, obojica se doimaju ,toliko duboko stopljeni [sa sredinom] da izgleda kako za njih uopće nema mjesta“ (Miller, 2007, 132). U tom smislu, pokazat ćemo kako je upravo Stockmannova i Sokratova pozicija „unutrašnjeg drugog“ (Miller, 2007, 132) razlog zbog kojeg ih naposljetku njihovi sugrađani progone te ih krste nazivom neprijatelja naroda, građanstva, zajednice, većine.

Kako otkrivamo na početku Platonova dijaloga, povod Sokratovu rijetku izlasku iz matičnog okruženja raspoznaje se u predmetu koji Fedar čuva u njedrima, čarobnom predmetu koji skriva u džepu kaputa, u vlastitoj nutrini. Riječ je naime o dragocjenom objektu, Lisijinu pisanom govoru, o čijoj vrijednosti doznajemo kroz Sokratovu usporedbu teksta s ukusnim zalogajem. Budući da besjedu drži jedinim sredstvom kojim ga je mogao privoljeti da napusti zidine grada, Fedar je Sokratovim riječima, pronašao „liek neizlaženju, jer kano što gladno blago vode noseć pred njim granu ili kakvu hranu, tako i ti pružajuć mi govore u knjigama, čini mi se, vodit ćeš me okolo ciele Attike i kamo te drugamo volja“ (Platon, 1997, 7). Usporedivši dakle Lisijin pisani govor s lijekom (pharmakon), pojam se uvodi

${ }^{4}$ „PHAIDROS: A ti, čudni čovječe, baš se činiš neki osebujnjak, jer upravo kako veliš nalik si kakvu strancu, kojeg vode, a ne domaćem (čovjeku). Tako ni iz grada ne ideš u tudje krajeve, a čini mi se baš ni izvan zida ne izlaziš“ (Platon, 1997, 7).

${ }^{5}$ Govoreći o Sokratovoj privrženosti Ateni, Mihailo Đurić kazuje kako je on ,pravi atinski rodoljub koji u svakom trenutku misli na slavu i veličinu svoga grada“ (Đurić, 1968, 10). O Stockmannovom rodoljublju svjedoče njegove brojne izjave poput tvrdnje kako „nema lepšeg osećaja nego kad čovek zna da je uistinu stekao zasluge za domovinu i svoje sugrađane“ (Ibsen, 1968, 26) te ispovijest u četvrtom činu u kojem među ostalim kaže: „Voleo sam svoje rodno mesto tako toplo kao što iko može voleti svoj zavičaj u kome je proveo srećno detinjstvo [...]. Raditi neumorno i vatreno na opštem dobru, a naročito na dobru moga rodnog mesta, to mi je bila najvatrenija želja“ (Ibsen, 1968, 75). 
u razgovor kao objekt želje, objekt koji neodoljivo privlači, premda objekt koji, kao i obrok, može imati i blagotvoran i štetan učinak. Poput goveđeg pečenja koje miriše u prvom prizoru Ibsenova komada i koje suradniku Narodnog glasnika Bilingu neizrecivo prija, dok Peter Stockmann isto jelo odbija jer mu večernji obrok škodi, pisani govor neće imati isti učinak na svakoga recipijenta.

Kao što Derrida ističe u svojoj glasovitoj analizi Platonovo ljekarništvo (La pharmacie de Platon) (1972), djelovanje zamamnog objekta-obroka, govora u knjigama (logoi en bibliois), proizlazi upravo iz njegova statusa zagonetke: „samo riječi koje su odgođene, zatvorene, zamotane, savijene“, odnosno riječi koje Sokrat iščekuje i priželjkuje tijekom šetnje, otkrivaju se kao razlog izlaska, kao objekt-uzrok želje (Derrida, 1981, 71). Budući da je nagnao Sokrata da skrene sa svojega puta, moć pharmakona za Derridu se očituje kroz pokret i u neprekidnoj mijeni, u nestalnosti i neuhvatljivosti koja podsjeća na kretanje tekućine ${ }^{6}$, na klizanje vode kada je pokušamo uhvatiti rukom. Omamljeni dražima pharmakona, neuhvatljivošću pisma, njegovom fluidnošću, nužno ćemo i sami zalutati i zabludjeti, pa nam se tako može učiniti da, kada je pismo Ibsenove drame u pitanju, postoji jedan smjer kao jedan smisao ili ideja. Najavljujući naime bratu članak koji tek treba objaviti, a o sadržaju kojeg mu još uvijek ne želi govoriti, doktor Stockmann svoj tekst predstavlja kao zagonetku, kao još uvijek krajnje nesiguran i dvosmislen rad, rad koji zasad nema jedan zaključak:

STOCKMANN (zastane): To ti, Petre, u ovom trenutku još ne mogu reći. U svakom slučaju, večeras još ne. Možda će prilike ostati sasvim neobične, a možda će sve ostati po starom. Možda je to samo uobraženje...

PREDSJEDNIK: To mi zvuči sasvim zagonetno. Da se ne valja nešto iza brda? Nešto što hoćeš od mene da zatajiš? (Ibsen, 1968, 14).

Da pharmakon uvijek zavod i na krivi put te da podrazumijeva političko razmimoilaženje, supostojanje dvaju smjerova mišljenja i djelovanja kao neotklonjivog antagonizma, naslućujemo u dijalogu dvojice braće od kojih svaki za onoga drugoga misli da je zastranio:

${ }^{6}$ Budući da se u tekućem stanju ,suprotnosti lakše miješaju“ (Derrida, 1981, 152), voda je, prema Derridinom tumačenju, tvar koja je najpodložnija kontaminaciji. Štoviše, Derrida izrijekom kaže: „, [t]ekućina je element pharmakona“ (Derrida, 1981, 152). 
PREDSJEDNIK: [...] moram najodlučnije zahtevati da sva naređenja idu propisnim putem, po nadležnosti. Ne mogu dopustiti da se udari stranputicom.

STOCKMANN: Jesam li ja ikad udario stranputicom?

PREDSJEDNIK: Svakako imaš uređenu sklonost da uvek ideš svojim sopstvenim putem, a to se u dobro uređenoj zajednici gotovo tako isto ne može dopustiti. Pojedinac se uvek mora pokoriti celini, ili - da se tačnije izrazim - vlastima koje imaju da se staraju o blagostanju celine. [...]

STOCKMANN: Ali, jesi li lud? Ti si sasvim na pogrešnom putu! (Ibsen, 1968, 14-15).

Kao i na Farmakijinu vrelu, na kojem se ljekovito svojstvo okreće, prelazi i pretače u svoju suprotnost, na norveškom kupalištu koje je osmišljeno u terapijske svrhe liječnik je pronašao otrovno djelovanje opasno po zdravlje. Isti princip neodređenosti zamjećujemo i u opreci prijatelja i neprijatelja naroda, odnosno stranaca i domaćina - kao svojevrsni nastavak igre u kojoj je Farmakija „u smrt odvukla djevičansku čistoću i neprobijenu unutrašnjost" (Derrida, 1981, 70). Ističući kako se pisani tekst uvodi u tijelo Platonova dijaloga u svoj svojoj ambivalenciji, Derrida opisuje mnogostrukost značenja pharmakona počevši od njegova magičnog svojstva koje smo istaknuli u Sokratovu doživljaju Lisijina pisana govora. Osim što dakle može začarati slušatelje, opčiniti znatiželjnike žedne pisane riječi ili ih nagnati da skrenu sa svojih ustaljenih putova, pharmakon može djelovati i štetno i korisno, označavajući u isto vrijeme i ,pomoć“, i „recept", i ,otrov“, i ,lijek“, i „magnet“ itd. (Derrida, 1981, 71).

Poput pharmakona, čiju srž Derrida opisuje u terminima nedostatka stabilnog sadržaja, tvrdeći pritom da pharmakon nije supstanca, bilo u metafizičkom, fizičkom, kemijskom i alkemijskom smislu riječi (Derrida, 1981, 125-126), Stockmannova istina utjelovljuje, kako u svojoj pojavnosti, tako i u svojim učincima, neuhvatljivu drugost, razliku razlike koja se stoga ne može niti tiskati niti priopćiti. Osim toga, sam pisani dokument okuplja više dijelova: uza svežanj papira koji se sastoji od četiri arka na kojima autor detaljno obrazlaže svoje uvide, Stockmann prilaže labaratorijski nalaz koji služi kao službena ovjera napisanog teksta te sve potom omotava novinskim papirom. Kao što smo maloprije istaknuli, iz Derridina tumačenja pharmakona, Stokmannov se tekst pokazuje kao „odgođen, zatvoren, zamotan, savijen“ (cf. Derrida, 1981, 71), skriven i nikad objavljen. Drugim riječima, Stockmannova istina istovremeno funkcionira kao pharmakon u tekstu, kao lijek i otrov za zajednicu te kao tekst 
o pharmakonu, pismo u kojem se govori o prisutnosti štetne tvari u ljekovitoj vodi.

Unatoč tome što je u svojim dosadašnjim radovima, u brošurama i seriji članaka objavljenih u Narodnom glasniku, pisao preporuke za gradsko kupalište tvrdeći kako je riječ o „neobično zdrav[om] mest[u] ... mest[u] koje zaslužuje da se najtoplije preporuči i bolesnima i zdravima“ (Ibsen, 1968, 22), liječnik je sada prisiljen potpisati suprotno. Iz pisma koje mu u četvrtom prizoru prvog čina dospijeva u ruke, Stockmann doznaje da se u uzorku vode koji je poslao na analizu ,nalaze trule organske materije, milioni bakterija“" (Ibsen, 1968, 23). Nakon što su se simptomi bolesti pojavili u nekolicine gostiju kupališta, liječnik je isprva posumnjao da su turisti-tuđinci nositelji kakve zaraze, da bi sada shvatio kako se izvor bolesti krije među domaćim sanovništvom, da se upravo u njihovoj zajednici nalazi žarište i rasadište bakterija, pravo „leglo kuge“ (Ibsen, 1968, 22).

Kupalište koje se dosad smatralo ključnim čimbenikom za gospodarski i društveni razvoj regije i koje je Stockmann opisivao kao žilu kucavicu, kao „životni nerv, pluća, bilo“ grada, odnosno kao „srce i dušu“ (Ibsen, 1968, 22), nakon novih spoznaja najednom se pretvara u kolektivnu ,grobnic[u]“ (Ibsen, 1968, 23). Otkrivajući se kao nositelj mogućnosti ponovnog rođenja, procvata i regeneracije, motiv vrela pokazuje se u značenju resursa: prirodnog bogatstva koje može osloboditi zajednicu bolesti siromaštva, odnosno preporoditi njezino gospodarstvo. Ponovno, kao i u slučaju pharmakona, ,ono što se na jednoj razini doima ljekovitim, na drugoj se pokazuje otrovnim“ (Miller, 2007, 150), pa tako Stockmannovo otkriće donosi zdravstvenu blagodat, ali i ogromnu financijsku štetu: budući da kupalište koje je trebalo osigurati prosperitet zajednice u cijelosti treba srušiti, Stockmann će, prema mišljenju njegova brata, „upropasti[ti] svoje rodno mjesto“ (Ibsen, 1968, 38). Uvidjevši da se u pogledu stanja vodovoda sudaraju dvije perspektive, jedna „naučna“, a druga „tehničko-privredna“ (Ibsen, 1968, 42), za Petra Stockmanna stvar se doima „složen[om]“ (Ibsen, 1968, 42), dočim za Thomasa nema dvojbe da istina nema dvije strane. Stoga i može, potaknut Bilingovim zaključkom kako će postati ,prvi čovek u mestu“ (Ibsen, 1968, 25), početi sanjati o slavi koju će mu otkriće donijeti. Uvjeren isprva kako će se predsjednik kupališta ,od srca radovati što je tako važna istina objelodanjena“ (Ibsen, 1968, 25), Stockmann u potpunosti griješi u procjeni pa će 
namjesto prvoga postati zadnji čovjek u gradu, namjesto da ga slave kao heroja, izopćit će ga.

Motiv nečistog identiteta zamjećuje se nadalje u sporu dvaju Stockmanna oko autorstva: bratsko rivalstvo ogleda se u tome što obojica svojataju zasluge smatrajući da je kupalište isključivo njihovo djelo, objekt koji predstavlja plod njihova uma i djelovanja. Ustvrdivši kako je doktor Stockmann ,stvorio [...] kupalište“ (Ibsen, 1968, 10), kako je upravo njegov intelekt ishodište i zametak čitavog projekta, Hovstad naglašava „da je prva ideja [...] potekla od doktora“" (Ibsen, 1968, 10). U nevjerici slušajući kako urednik gleda na stvar, Petar Stokmann, kao predsjednik kupališnog društva, podsjeća da valja u obzir uzeti i njegov ,skromn[i] ud[io] u tom preduzeću“ (Ibsen, 1968, 10) posebice stoga što je njegov brat $\mathrm{i}$ inače sklon idejama, a ne djelima: „A, ideja je moj brat celog svog veka imao dosta - na žalost! Ali kada treba nešto provesti u delo, onda se tu traže drugi ljudi, gospodine uredniče“ (Ibsen, 1968, 10). Budući da urednik potvrđuje kako je stariji brat doista čitavu „stvar pokrenu[o] i praktično izve[o]“" (Ibsen, 1968, 10), čitateljima ne preostaje drugo do li zaključiti da obojici braće pripada pravo na očinstvo projekta. Poput autorskog dvojca u Heddi Gabler, Løvborga i Thee, koji su skupa radili na knjizi-djetetu, kupalište je plod zajedničkog truda Thomasa i Petera, pri čemu se prvi iskazao u teorijskom, a potonji u praktičnom pogledu. Nakon prepirke dvojice braće u drugom činu, kasnije se ponovno pokreće ista rasprava o autorstvu rada, u kojoj Thomas ističe kako se godinama pokušavao izboriti za svoju ideju: „i pisao sam, pisao“ (Ibsen, 1968, 40), a Petar se nadovezuje na njegove riječi ustvrdivši kako je nakon toga on „uzeo stvar u svoje ruke“ (Ibsen, 1968, 41).

Za Thomasa Stockmanna, doktora-piskarala, riječi su poput vode koja se neprestano izlijeva iz korita, one su u stalnom porastu, nadiru sa svih strana poplavljujući listove, zatim „brošure i članak za člankom“ (Ibsen, 1968, 22). Ulazeći u redakciju časopisa, Stockman uzvikuje:

Štampajte, gospodine uredniče, štampajte slobodno! [...] Štampajte slobodno, velim! [...] Ovaj članak je samo uvod. Već imam glavni nacrt za četiri, pet drugih. [...] o sasvim drugim stvarima. Ali sve dolazi od vodovoda i kanalizacije. Jedna stvar neizbežno povlači za sobom drugu (Ibsen, 1968, 48).

Unatoč žarkoj želji autora da se tekst što prije pojavi u novinama, „da ga izbaci[] u svet“ (Ibsen, 1968, 49), Stockmannov članak uporno ne 
uspijeva doživjeti svoj otisak. Nakon što je naime Petar Stockmann razgovarao s urednikom časopisa i vlasnikom tiskare te nakon što ih je uvjerio da je liječnik ,stvar predstavi[o] u lažnoj svetlosti“ (Ibsen, 1968, 64), u komadu se postavlja pitanje na koje nailazimo u Platonovu Fedru: mora li govornik poštivati istinu predmeta o kojem govori ili se treba voditi samo onime što se sviđa slušateljima? (cf. Platon, 1997, 42). Shvativši da će nakon liječnikova otkrića općina morati podići zajam, odnosno da će građani morati iz svojega džepa otplaćivati popravak vodovoda te da će, osim toga, građani izgubiti prihode dok traju radovi, Aslaksen i Hovstad postaju svjesni da se Stockmannov sastavak neće svidjeti njihovoj publici te stoga gube svaki interes za pitanje istine. Utoliko što Narodni glasnik predstavlja glas čitatelja, tumači Aslaksen Stockmannu, slova nisu u vlasti onoga koji ih uređuje ili tiska, kao što uostalom nisu u vlasti onoga tko ih piše, nego u rukama naroda, u vlasti recepcije:

STOCKMANN: [...] Ta vi ste urednik; a ja mislim da listom upravlja urednik.

ASLAKSEN: Nije tako, gospodine doktore; listom upravljaju pretplatnici.

PREDSJEDNIK: Srećom, tako je!

ASLAKSEN: Javno menje, prosvećeno građanstvo, sopstvenici kuća i svi ostali - jest, oni upravljaju listom (Ibsen, 1968, 64).

Za Sokrata samo je onaj tko posjeduje znanje o predmetu govora u poziciji da uvjeri slušatelje i eventualno promijeni njihove početne sudove, kao što je Sokrat uspio navesti Fedra da promijeni mišljenje u pogledu sofističke retorike. Dok Fedar isprva tvrdi da dobar govornik ne mora znati istinu o onome što je naumio govoriti, ,nego ono, što se svidi množini, koja će odlučivati“ (Platon, 1997, 42), Sokrat mu - navodeći primjer čovjeka koji kupuje magarca misleći da je konj - ukazuje na zabludu govornika koji se oslanja na ono „što se narodu svidja“ (Platon, 1997, 43), na sud slušatelja, gledatelja, čitatelja, počevši od atenske političke publike. Kako tumači Harvey Yunis, u demokratskim uvjetima političari postižu uspjeh rabeći sofističko pseudoumijeće retorike, umijeće koje Sokrat suprotstavlja blizanačkim zanimanjima: filozofu i liječniku (cf. Yunis, 2005, 11). Za razliku od znalaca, sofistima se može dogoditi da pođu u bitku na magarcu umjesto na konju, pa stoga počesto ispadaju smiješni - a opet bolje da su smiješni, nastavlja Sokrat, nego da su neprijatelji naroda (cf. Platon, 1997, 43). 
Budući da Stockmannov tekst odbijaju i urednik novina i vlasnik tiskare, koji ne želi čak ni tiskati Stockmannov „rukopis kao letak“ o vlastitu trošku i u vlastitu izdanju (cf. Ibsen, 1968, 65), liječnik se odlučuje okrenuti drugom mediju pa umjesto pisma odabire govor. Iako ga Petar i Aslaksen pokušavaju odgovoriti od ideje da svoj članak pročita na velikom narodnom zboru, Stockmann kazuje da ga ništa neće spriječiti u njegovome naumu, pa ako mu nitko ne bude htio iznajmiti prostor, platit će bubnjara pa ,prokrstarit s njim celo mesto i na svakom uglu čitati svoj članak“ (Ibsen, 1968, 66). Dok mu se vlastiti brat otkriva kao glavni suparnik, kapetan Horster postaje liječnikov sudrug: nakon što su ga svi redom odbili, Horster mu jedini odlučuje ustupiti dvoranu u svojem domu kako bi organizirao skupštinu građana. Braća po upraviteljskim pozicijama, liječnik i kapetan udružuju se u borbi protiv vladavine ,prost[og] čovek[a]“, odnosno svoje „neznalačk[e] umno nezrel[e] subra[će]““ (Ibsen, 1968, 79), zagovarajući poštivanje stroge hijerarhije i vlasti prosvijećenih, nositelja činova i zvanja. Kao što primjećuje Brian Johnston, u kapetanovoj replici iz prvog čina naslućuje se odjek glasovite misli iz šeste knjige Platonove Republike, misli da demokracija nipošto ne može funkcionirati na brodu (cf. Johnston, 2006, 139) ${ }^{7}$.

Kako saznajemo iz didaskalija, na skupštinu građana pristigli su mještani svih staleža, pa čak i žene i đaci, oboružani kazališnim rekvizitima: zviždaljkom i rogom. Nakon što se govornik međutim pojavio na pozornici držeći u ruci svoj rukopis, Aslaksen mu oduzima riječ da bi zatim predsjednik predložio okupljenima da se Stockmannu uopće ne dopusti održati predavanje „,bilo doslovno bilo u slobodnom obliku“ (Ibsen, 1968, 71). Optuživši Stockmanna da njegovo navodno predavanje o stanju kupališta nije ono za što se predstavlja, da je zapravo sadržaj njegova teksta nešto sasvim drugo, riječju, sredstvo političke manipulacije, Aslaksen tvrdi: „On govori o kupalištu; ali ono na što on smera, to je prevrat u našem gradu: on hoće da gradska uprava pređe u druge ruke“ (Ibsen, 1968, 72). Kada je trebalo glasati o prijedlogu da se Stockmannu oduzme pravo na riječ, Stockmann pak sam odlučuje promijeniti smjer govora koji je

${ }^{7}$ „BILING: [...] Društvo nije kao lađa. Svi koji su na lađi moraju da pomognu upravljati njome.

HORSTER: Na suvu to može biti dobro; ali na lađi bi se time stekla rđava iskustva“ (Ibsen, 1968, 17). 
trebao pročitati te kazuje: „Nije potrebno! Večeras ne mislim uopšte govoriti o svoj onoj prljavštini tamo dolje u kupalištu, nego treba da čujete nešto sasvim drugo" (Ibsen, 1968, 73). Prisiljen najprije promijeniti medij i uputiti se u drugom pravcu, sada nakon što je optužen da ne govori ono što tvrdi, odlučuje doslovno skrenuti s teme i u posljednji čas pred nastup promijeniti svoj govor. Uvidjevši da se u pitanju onečišćenja vode zrcali puno dublji problem, problem izopačenosti čitavog društveno-političkog uređenja, Stockmann umjesto detaljnog medicinskog i biokemijskog izvještaja podastire svoj nalaz duhovnog stanja naroda: „Rekoh da ću govoriti o velikom otkriću koje sam za ovo nekoliko poslednjih dana učinio, a to je: da su svi naši duhovni životni izvori otrovani, i da celo naše građansko društvo počiva na kužnom zemljištu laži“ (Ibsen, 1968, 74). Udaljivši se od najavljene teme izlaganja, Stockmann smatra da ga je početni uvid samo približio pravom ishodištu bolesti društva: ,nauk da je mnoštvo, gomila, masa, prava jezgra naroda - štaviše, da je ona sam narod i da prost čovek, taj naš neznalački, umno nezreli sabrat, ima isto pravo da presuđuje, da vlada i da upravlja kao i ona šaka umno otmenih i slobodnih ljudi“ (Ibsen, 1968, 79). Kako naime Stockmann predlaže u svojem govoru, upravo je demokratski poredak izvorište moralne zatrovanosti i iskvarenosti, žarište bolesti društvenog organizma iz kojeg istječu sve boljetice njegova grada-zajednice.

Kao što je uzalud molio uredništvo Narodnog glasnika da objave njegovu raspravu unatoč optužbama da se u njoj ,stvar predstav[lja] u lažnoj svetlosti“ tvrdeći da će je on „već umeti odbraniti““(Ibsen, 1968, 64), Stockmann ni u usmenom obliku ne uspijeva otkloniti nerazumijevanje slušatelja. Iako za Sokrata neadekvatnost pisane riječi proizlazi iz činjenice što ne mogu nego šutjeti, u Ibsenovu metadramskom prijepisu Platonova dijaloga izgovorene su riječi kanda jednako nijeme, uporno ne dopiru drugome do ušiju. Sokrat naime tvrdi da pisana riječ:

tumara ovamo i onamo, isto tako k onima koji je ne razumeju kao i onima kojima nije namenjena, pa se ne zna s kime treba govoriti, a s kime ne. A zlostavljena i nepravično ružena uvek treba roditelja kao pomoćnika: jer sama niti može sebe odbraniti niti sebi pomoći (Platon, 1970, 176) ${ }^{8}$.

${ }^{8}$ Zbog arhaičnosti hrvatskog prijevoda, ovdje iznimno upućujem na srpski prijevod (cf. Platon, 1997, 63). 
Iako usmeni govor pretpostavlja mogućnost koju pismo ne dopušta da pojasni i obrazloži svoju poziciju, da odgovori na napade i time otkloni nesporazum - Stokmannov govor ostaje neizgovoren, a dijalog dviju suprotstavljenih strana nemoguć. Kako otkrivaju didaskalije, uzvici iz mnoštva, smijeh i zvižduci pojačavaju se nakon svakog Stockmannova dodatna obrazloženja pri čemu je Aslaksen - u funkciji predsjednika skupštine prisiljen prekidati viku i lupanje nogama zvoncem i opomenama. Oduzevši mu naposljetku riječ jer je vrijeđao publiku, narodna skupština nakon provedenog glasanja donosi presudu prema kojoj se Thomas Stockmann proglašava narodnim neprijateljem.

U skladu s promjenjivom prirodom pharmakona, Stockmannova istina, koja nije uspjela pronaći svoj izraz ni u usmenom ni u pisanom obliku, u petom činu zadobiva mogućnost nove preobrazbe. Tvrdeći da se pravi razlog Stockmannova napada na kupalište nalazi u nastojanju da zgrne bogatstvo za svoju obitelj, Petar mu obznanjuje kako je njegov punac kupovao akcije kupališta i kako je u svojoj oporuci predvidio da veliki dio svoga imanja pripadne Stockmannovoj djeci, a da on i supruga do smrti uživaju prihode od imanja. Budući da se u svjetlu novih spoznaja povod Stockmannovu tvrdoglavu inzistiranju može protumačiti na posve drukčiji način - kao puka želja za osobnom financijskom koristi, pismo kao pharmakon ponovno se otkriva upravo u dimenziji neuhvatljivog. Užasnut optužbama, Stockmann dočekuje Aslasena i Hovstada koji, namirisavši novac, dolaze ponuditi liječniku da naposljetku objavi svoj rad u njihovim novinama, upozorivši ga da mogu stvar „dvojako prikaz[ati]“ (Ibsen, 1968, 100).

Spomenuti antagonizam u središtu poretka reprezentacije upućuje nas u smjeru završnog sraza političke i metateatarske dimenzije Ibsenove drame: s obzirom da nije niti pristao otići iz rodnog mjesta, niti je uspio ostvariti svoj zamišljaj društvenog zajedništva i jednine, čistog poput netaknutog izvora vode, Stockmann ostaje u svijetu u kojem se stvar uvijek može prikazati dvojako i shvatiti različito, svijetu u kojem zbog toga dijalog ne prestaje teći, i teći, i teći.

Slijedom strukturne analogije Stockmannove istine - uvida da se izvor bolesti krije u srcu društvena organizma te spoznaje da se patološka 
dimenzija nalazi ugrađena $u$ temelje sociopolitičkog poretka - u radu smo pokazali kako Ibsenova drama opetovano iznosi na vidjelo nečistoću identiteta: kužnu i trulu ,jezgr[u] naroda“ (Ibsen, 1968, 79). Suprotstavljajući se vladavini većine u narodnoj skupštini, Stockmann upozorava da se središte ne nalazi na svom mjestu: da ,prav[u] jezgr[u] naroda“ treba tražiti među „umno otmeni[m] i slobodni[m] ljudi[ma]“ (Ibsen, 1968, 79). Poput Sokrata, koji se ,ponaša kao stranac iako je rođeni Atenjanin“ (cf. Ferrari, 1987, 13-14), Stockmann u dramskoj završnici zadržava svoj položaj unutrašnje isključenosti, pa odustaje od traganja za drugim svjetovima i ostaje živjeti u svojoj zajednici kao izopćenik. $\mathrm{Na}$ tragu etimološke bliskosti pojmova pharmakon - pharmakeus - pharmakos na koju u svojoj analizi ukazuje Derrida (cf. 1981, 129) dade se zaključiti da Stokmann naposljetku sam utjelovljuje izmještenu jezgru naroda: preuzima funkciju žrtvenog jarca (pharmakos) te postaje neprijatelj i krivac, trovač i kvaritelj.

\section{Literatura}

Brustein, R. (1991). The Theatre of Revolt: an Approach to the Modern Drama. Chicago: Elephant Paperbacks.

Derrida, J. (1981). Dissemination. Prev. B. Johnson. Chicago: The University of Chicago Press.

Đurić, M. (1968). Sokrat i sofisti. U: Protagora - Gorgija. Beograd: Kultura, str. 5-43.

Ferrari, G. R. F. (1987). Listening to the Cicadas. A Study of Plato's Phaedrus. Cambridge: Cambridge University Press.

Figueiredo, I. de (2011). Henrik Ibzen: Maska. Prev. M. Popin-Ćorić. Sremski Karlovci - Novi Sad: Izdavačka knjižarnica Zorana Stojanovića.

Ibsen, H. (1968). Neprijatelj naroda. Prev. S. Perišić. Zagreb - Beograd: Epoha - Komerc-union.

Ibsen, H. (1978). An Enemy of the people. U: Ibsen. The Complete Major Prose Plays. Prev. R. Fjelde. New York: Farrar, Straus, Giroux, str. 277-86.

Johnston, B (2006). The Poetry of An Enemy of the People. U: Turning the Century. Centinnial Essays on Ibsen. Ur. M. Robinson. Norwich: Norvik Press, str. 135-145.

Miller, P. A. (2007). Postmodern Spiritual Practices. The Construction of the Subject and the Reception of Plato in Lacan, Derrida, and Foucault. Columbus: The Ohio State University Press.

Platon (1970). Iljon; Gozba; Fedar. Prev. M. Đurić. Beograd: Kultura.

Platon (1997). Fedar. Prev. F. Petračić. Zagreb: Naklada Jurčić. 
Van Laan, T. F. (1986). Generic Complexity in Ibsen's „An Enemy of the People“. „Comparative Drama“ vol. 20, br. 2, str. 95-114.

Williams, R. (1979). Drama od Ibzena do Brehta. Prev. M. Frajnd. Beograd: Nolit.

Yunis, H. (2005). Introduction. U: Phaedrus. Ur. H. Yunis. Cambridge - New York: Cambridge University Press, str. 1-31. 